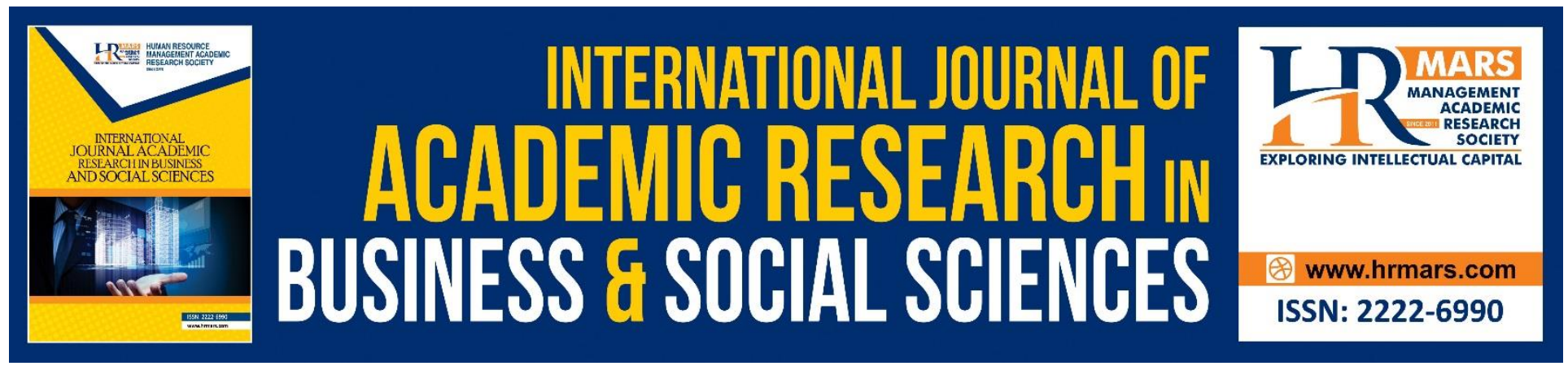

\title{
Strategic Business Practices and Performance of Hotels in Eritrea
}

\author{
Isaiah Gituma, Tuccu Tewolde
}

To Link this Article: http://dx.doi.org/10.6007/IJARBSS/v9-i1/5502

DOI: $\quad 10.6007 /$ IJARBSS/v9-i1/5502

Received: 17 Dec 2018, Revised: 25 Jan 2019, Accepted: 11 Feb 2019

Published Online: 15 Feb 2019

In-Text Citation: (Gituma \& Tewolde, 2019)

To Cite this Article: Gituma, I., \& Tewolde, T. (2019). Strategic Business Practices and Performance of Hotels in Eritrea. International Journal of Academic Research in Business and Social Sciences, 9(1), 1014-1029.

Copyright: (C) 2019 The Author(s)

Published by Human Resource Management Academic Research Society (www.hrmars.com)

This article is published under the Creative Commons Attribution (CC BY 4.0) license. Anyone may reproduce, distribute, translate and create derivative works of this article (for both commercial and non-commercial purposes), subject to full attribution to the original publication and authors. The full terms of this license may be seen at: $\underline{\text { http://creativecommons.org/licences/by/4.0/legalcode }}$

Vol. 9, No. 1, 2019, Pg. 1014 - 1029

http://hrmars.com/index.php/pages/detail/IJARBSS

JOURNAL HOMEPAGE

Full Terms \& Conditions of access and use can be found at http://hrmars.com/index.php/pages/detail/publication-ethics 


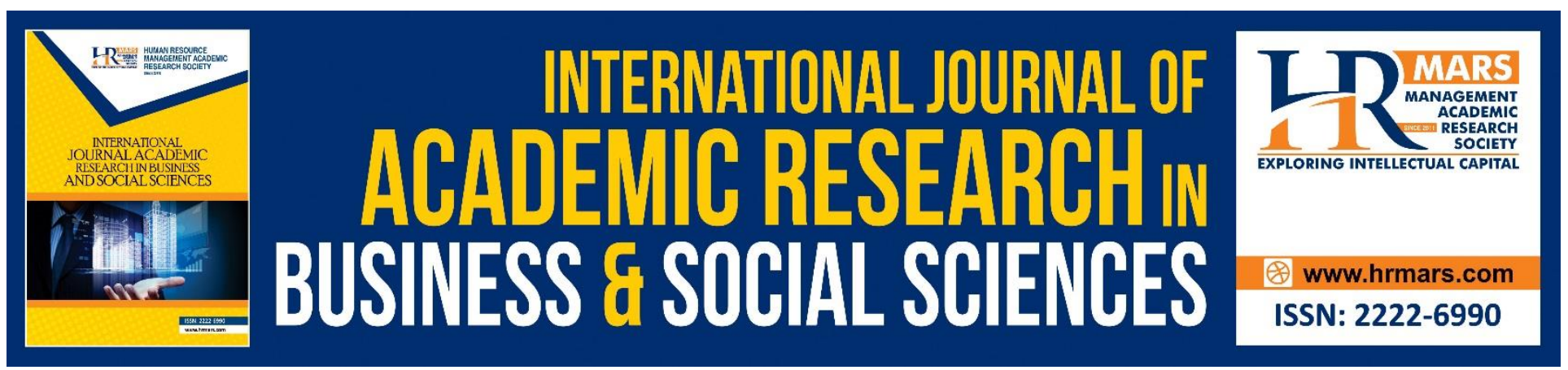

\title{
Strategic Business Practices and Performance of Hotels in Eritrea
}

\author{
${ }^{1}$ Isaiah Gituma (PhD) ${ }^{2}$ Tuccu Tewolde (PhD) \\ College of Business and Economics, Asmara Eritrea \\ Email: mgituma2013@gmail.com, tuccu44@gmail.com
}

\begin{abstract}
The hotel sector is a critical component of the tourism industry because it is the bedrock for the supply of other tourism services. Owing to the sector's phenomenal role in the tourism industry, its performance is deemed critical. To live up to this performance expectation, hotels employ varied strategic business practices in a bid to gain competitive edge in the industry. Therefore, this research sought to establish the relationship between strategic business practices and performance of hotels in Eritrea. Cross-sectional descriptive and explanatory research designs were employed. The study population comprised 64 hotels with 64 purposively selected hotel managers or/and ownermanagers as the respondents. Self-administered questionnaires were used to collect primary data. Descriptive statistics were computed to describe the characteristics of the study variables while inferential statistics were computed to establish the relationships among study variables. The regression analysis yielded adjusted $\left.R^{2}=0.278 ; P=0.000<0.05\right)$. This means that strategic business practices (independent variables) collectively accounted for $27.8 \%$ of the variability in the performance of the hotels. The study also found that $65.6 \%$ of the hotels surveyed did not have business plans, strategic plans or marketing plans. Owing to the findings, the study recommends a more deliberate and intentional approach to the use of strategic management tools such as strategic plans, business plans as well as marketing plans that were found to be conspicuously missing in the surveyed hotels. The use of such tools would appropriately guide the management in the appropriate selection and use of competitive strategies to meet organizational objectives.
\end{abstract}

Keywords: Strategic Business Practices, Organizational Performance, Competitive Pricing, Product Specialization, Corporate Branding, Product Differentiation, Skilled Employees.

\section{Introduction}

The hotel sector is a major component of the tourism industry in any country and therefore measurement of its performance is crucial. Moreover, performance measurement is a basic element of business management that aims at providing understanding on the source of a sector's competitiveness. In general, firm's performance relates to both external and internal factors; 
external, because firms compete in sectors and markets which influence strategy and results; and internal, because firms have to choose strategies as well as best practices to be adopted and/or adapted in order to improve performance (David, 2001; Mintzberg, 1990). Strategic business practices help business firms to gain leverage over competition and to also creatively allocate the firm's scarce resources. This in effect is deemed to increase operational efficiency and effectiveness thus facilitating attainment of desired organizational goals. Rhyne (1986) observes that without a clearly defined strategy, a business has no sustainable basis for creating and maintaining a competitive edge in the marketplace.

However, despite the extant literature on strategic management being replete with models that show their efficacy in influencing organizational performance, the empirical applications are still limited especially in the hotel industry and more so in developing countries. Therefore, studying strategic business practices appropriated in the hotel industry contributes to the understanding of the nexus between the strategies used and organization performance (Hitt \& Hornsby, 2005; Ng'ang'a, 2013 \& Musyoka, 2016). Nevertheless, available literature and previous researches have mainly focused on performance of big hotels; 3-5 star hotels in developed countries. Consequently, there has been little focus on strategic business strategies used in smaller hotels especially in developing countries and their effect on performance (Perry, 2001; Gibuson \& Kemp, 2005). This study therefore focuses on the strategic business strategies utilised by hotels in Eritrea, which is a developing country in Africa, in a bid to establish their effect on hotel performance. All hotels used were of less than 3-star rating. The study sought to test the following hypotheses;

$\mathrm{H}_{\mathrm{a} 1}$ : Hotel performance in Eritrea is positively related to competitive pricing $\mathrm{H}_{\mathrm{a} 2}$. Hotel performance in Eritrea is positively related to product specialization $\mathrm{H}_{\mathrm{a} 3}$. Hotel performance in Eritrea is positively related to corporate branding $\mathrm{H}_{\mathrm{a} 4}$. Hotel performance in Eritrea is positively related to product differentiation $\mathrm{H}_{\mathrm{a} 5}$. Hotel performance in Eritrea is positively related to employee training

\section{Strategic Business Practices and Organizational Performance}

Strategic business practices also referred to as competitive strategies, refer to the courses of action that an organization designs and implements in a bid to achieve its desired objectives and to also be the best in the industry by gaining leverage over its competition. The need for strategic management of businesses presently obtains owing to the dynamism of the business macro-environment; politicallegal, economic, socio-cultural, technological, ecological and demographic factors as well as the need to respond to the micro-environment pressure arising from both stakeholder and shareholder expectations. This is further compounded by the surging competition arising from increasing levels and speed of innovating business products to satisfy the needs of a more demanding clientele. In the hotel industry, the key to attracting and winning customer loyalty is by offering an unforgettable experience. This calls for high levels of innovativeness and application of strategies that ensure provision of superior customer service to hotels' varied clientele. In this context, technology becomes an integral strategic asset that allow hotels to improve their competitiveness, effectiveness, efficiency, and customer satisfaction, whose resultant effect is sales growth and profits, the ultimate 
indicators of performance in the hospitality industry (Nyheim, McFadden \& Connolly, 2004).

Researchers postulate that the hospitality industry can achieve its performance objectives if it can adopt or adapt dynamic business management strategies in its operations. Khan and Fasih (2014) opines that an organization can be more efficient by using operational excellence to decrease operational and cycle time used to provide a certain service to clients while Njoroge (2013) observes that hotels can perform better if the skills-set of the employees in different hotels are relevant to the mission of the firm. Musyoka (2016) argues that management style and competence are essential in enforcing the policies and guidelines set out by the top management in hotels to promote effectiveness and efficiency, which are the hallmarks of performance in the service industry. Ng'ang'a (2013) identified the following strategies as being critical in the hotel industry: leadership, personal contact, extensive staff training, strategies on quality customer service, physical attractiveness, range of product offerings, unique product features, safety and security systems, and information technology, among others.

\section{Organizational Performance}

Organizational performance is the outcome of the varied strategies that an organization puts in place to achieve its desired objectives. In the context of a hypercompetitive and highly dynamic business environment that is also characterised by scarce resources and rising stakeholder and shareholder expectations, businesses find themselves under immense pressure to perform (Ng'ang'a, 2013; Neely, Mills, Platts, Richards, \& Gregory, 2000). Consequently, there is need to measure their performance. However, performance measurement is a challenging task owing to the lack of agreement on the measurement indicators among strategic management researchers and scholars (Santos \& Binto, 2012). Most researchers tend to use financial metrics to measure corporate performance (Combs, Crook \& Shook, 2005). However, financial measures only give historical data on organisational performance which may not accurately reflect the future performance of the organisation.

Organizational performance can be measured using financial and non-financial indicators (Zuriekat, Salameh \& Alrawashdeh, 2011). This proposition is supported by Kaplan and Norton (1992) who observe that organisations continuously invest in acquiring new capabilities and therefore their success (or failure) cannot be measured in the short-run by the traditional financial measures such as profit without taking organisational goals into consideration; a view that is shared by Lee and Nowell (2014) who indicate that emerging inadequacies in the financial performance measures have led to innovations of non-financial indicators mainly because it is believed that ultimately they affect profitability. Waiganjo, Mukulu and Kahiri (2012) also argue for wider performance constructs that incorporate aspects of non-financial measures such as effectiveness, efficiency, quality, and company image in addition to financial measures such as profits.

Traditionally, performance measurement in the hotel industry has placed heavy emphasis on the use of financial measures. However, presently, the role of non-financial indicators, such as customer satisfaction, quality assurance, workers' productivity, employee satisfaction, stakeholders' satisfaction, among others have become important as they determine the competitiveness of a 
business as well as its ability to sustain profitability in the future. Ng'ang'a (2013) opines that incorporation of non-financial indicators in performance measurement process is crucial particularly in the face of intense competition, shorter product life cycles and rapid advances in technology, which characterize the contemporary business. Moreover, performance measurement practices should be contextualized to reflect changes in business environment and environmental variables in hotel industry. This study measured performance of hotels using sales growth and profits.

\section{Statement of the Problem}

The need to study organizational performance in the hospitality industry in developing countries is crucial given that majority of related studies have focused on the developed countries (Musyoka, 2016). The heterogeneity of hotels and the context-dependent nature of their operations make it difficult to find "a best practice" strategy that a hotel should adopt in order to obtain its desired performance goals. Moreover, industry practitioners argue that hotel managers play critical roles in the choice of strategies to be implemented as performance goals may differ from one hotel to the other, even in the same context, owing to a number of variables such as age, size, star-rating, location, context, and owner-manager's experience, among others (Corgel \& deRoos, 1997; Delmar, Davidsson \& Gartner, 2003; O'Neill, 2004; O'Neill \& Xiao, 2006; Audretsch \& Dohse, 2007). This view is supported by strategic management literature that suggests firms can be successful by adopting management strategies that are suited to the environment in which they are applied (Parker, Storey \& Witteloostuijn, 2010).

Partially, due to the lack of sufficient industry-wide hotel performance data, especially in Africa, and the comparatively low levels of development in the hospitality industry in many countries in the region, few studies are available that have attempted to link business strategies and performance in the sector (Okumus, 2002; Ng'ang'a, 2013; Musyoka, 2016). However, although a few recent studies have sought to compensate for this limitation and have shown that hotel firms' strategies may have significant effect on hotel performance (O'Neill \& Xiao, 2006; O'Neill \& Mattila, 2010; Ng'ang'a, 2013; Musyoka, 2016), there is no known comprehensive research that has endeavoured to establish the strategic business practices adopted by hotels in Eritrea and their resultant effect on performance. Eritrea is one of the countries that has a lot of attraction features and sites for tourists and researchers in the Horn of Africa owing to its linkage with the discoveries of the earliest remains of humans and by extension linking it to the cradle of mankind; presence of numerous archaeological sites, its diverse natural landscape that is characterised by mountain ranges, its long Red Sea coastline, its documentation as a heritage site by UNESCO in 2017 and its unadulterated culture, among others. In this context, hotels can play an increasingly essential role in the provision of hospitality services to tourists. Owing to the foregoing, an investigation of the relationship between strategic business practices and performance of hotels is imperative. This study, therefore, sought to establish the effect of strategic business practices on performance of hotels in Eritrea. 


\section{Literature Review}

Strategic management researchers agree that strategies are the results of the strategic analysis of an organization, which focuses on an organization's external environment and its internal context (David, 2001; Mintzberg, 1990). The objective of a strategic decision is to make the best use of available skills and resources in an organization in relation to external variables in order to achieve the best possible performance. From a resource-based view (hereinafter referred to as RBV) of the firm, firm strategies are considered from an internal perspective, and previous studies have revealed that analysis of internal resources can enable firms to determine their potential or realized sources of competencies and capabilities. RBV considers the resources and capabilities of the firm as the source of sustainable competitive advantage (Barney, 1991). However, competitive advantage is gained through resources that are valuable, rare, imperfectly imitable, and without strategically equivalent substitutes (Mata, Fuerst, \& Barney, 1995). Moreover, RBV is concerned with the connection between internal resources, strategy and the performance of the organisation (Kiiru, 2015). Therefore, hotels ought to utilize business strategies that give them leverage over the competition.

Based on empirical evidence, a study by Parker et al. (2010) identified four functional strategies that accounted for hotel performance: human resources, customer services, administration/governance and marketing. An empirical study by Qin, Adler \& Cai (2012) in the Chinese domestic hotel companies established that their essential strategy elements were keeping cost low, rapid expansion, continuous innovation, focus on quality consistency, extensive training and indigenous Chinese cultural operational practices. Ibid (2012) found that strong hotel branding resulted into creation of new customer value which consequently led to improved revenue management, strong market positioning and improved hotel sales and profitability (O'Neill and Mattila, 2010; Hayes \& Ninemeier, 2007; Corgel (2002).

An empirical study by Gibson and Cassar (2005) based on 2,900 firms in Australia showed a positive relationship between strategic planning and performance. However, an examination of more than 20 studies reviewed by Coad (2009) found mixed results on the connection between firm performance and strategic planning. While strategic planning is often defined as the existence of planning documents (Gibson \& Cassar, 2005), some studies find that many small firms lack such documents (Lumpkin \& Dess, 1995). In addition, some studies of strategy in hotels, which question the rationality of strategy making, instead examine strategy-making processes other than the rational processes that are often suggested in the literature and are used by large firms (Verreynne \& Meyer, 2010). These ambivalences in findings necessitate a study in a different context to examine the nexus that exists between different strategic business practices used by hotels and performance. Following the outcome of empirical literature review, the current study used the following explanatory variables: competitive pricing, product specialization, corporate branding, product differentiation and employee training to predict organizational performance; measured by sales growth and profits. Figure 1 depicts the conceptualization of the study. 
Independent Variable

Strategic Business Practices

- Competitive Pricing

- Product Specialization

- Corporate Branding

- Product Differentiation

- Employee Training

\section{Dependent Variable}

Organizational Performance

- Sales Growth

- Profits

Figure 1: Schematic Diagram of the Conceptual Framework

Source: Researchers (2018)

\section{Research Methodology}

Research Design

The research employed mixed research design. Saunders, Lewis and Thornhill $(2009,2013)$ argue that no single research design exists in isolation and that a combination of different designs in one study enables triangulation and increase the validity of the findings. Consequently, this study used explanatory and descriptive research designs and it was cross-sectional in nature. Explanatory research establishes causal relationships between or among variables. In this study, the researchers sought to establish the causal relationships between strategic business practices (independent variable) and performance of hotels (dependent variable) in Eritrea. Descriptive research design on the other hand enables the researcher to capture a population's attributes and test hypotheses, and describe the current relationship of the variables under study in their context without manipulating them (Cooper \& Schindler, 2003; Saunders et al., 2009; Kothari \& Garg, 2014).

\section{Target population}

The research involved a survey of 64 hotels involving hotel managers or/and owner-managers that were purposively selected from the four most developed regions (hereinafter called Zobas) of Eritrea. Administratively, Eritrea is divided into six zobas. The unit of analysis therefore was the hotels while the units of observation were managers or/and owner-managers of the selected hotels. The data on hotels were obtained from the Ministry of Tourism. The population distribution is as shown on Table 1 below: 
INTERNATIONAL JOURNAL OF ACADEMIC RESEARCH IN BUSINESS AND SOCIAL SCIENCES

Vol. 9, No. 1, Jan, 2019, E-ISSN: 2222-6990 @ 2019 HRMARS

Table 1: Population Distribution by Zoba

\begin{tabular}{llcc}
\hline Zoba & City & Frequency & Percentage \\
\hline Maekele & Asmara & 36 & 56.3 \\
Debub & Mendefera & 8 & 12.5 \\
Gashbarka & Keren & 12 & 18.8 \\
North Red Sea & Massawa & 8 & 12.5 \\
Total & & $\mathbf{6 4}$ & $\mathbf{1 0 0}$ \\
\hline
\end{tabular}

Source: Researchers (2018)

\section{Data collection}

Primary data were obtained from the hotel managers or/and owner-managers using questionnaires that contained both open-ended and closed-ended items. Open-ended and closed-ended questionnaire items are critical in facilitating triangulation and also enabling the researcher to collect both quantitative and qualitative data whose combinative effect is critical in informing the study findings, drawing appropriate conclusions, and making generalisation of findings (Babbie, 2010).

\section{Data analysis}

Quantitative data were analysed using descriptive statistics such as frequencies and percentages; and inferential statistics such as multiple regression and correlation analysis in Statistical Package for Social Science (SPSS) version 20. Pearson's correlation coefficient was used to establish the relationship among different variables while the adjusted $R^{2}$ was used to explain the amount of variation in the dependent variable (hotel performance) explained by the independent variables of strategic business practices. Multiple regression analysis was conducted to establish the joint effect of the independent variable on the dependent variable. To make reliable inferences from the data, all the statistical tests were subjected to tests of significance at alpha level of 0.05 .

\section{Results and Discussions}

\section{Response Rate}

The researchers distributed sixty four questionnaires to the respondents. Table 2 shows the response rate.

Table 2: Response Rate

\begin{tabular}{lcc}
\hline Response Rate & Frequency & Per cent \\
\hline Filled and returned & 64 & 100 \\
Total & 64 & 100 \\
\hline
\end{tabular}

Source: Field Data (2018)

Results of Table 2 show that all the questionnaires that were distributed were filled and returned thus representing $100 \%$ success rate. 
INTERNATIONAL JOURNAL OF ACADEMIC RESEARCH IN BUSINESS AND SOCIAL SCIENCES

Vol. 9, No. 1, Jan, 2019, E-ISSN: 2222-6990 C 2019 HRMARS

\section{Demographic Information of Respondents and the Firm}

The researcher sought to establish the following attributes of respondents and the firm: gender, education level, position held, and business ownership type, in a bid to determine their suitability in the study. Table 3 gives the results.

Table 3: Characteristics of Managers/Owner-managers and the Firm

\begin{tabular}{|c|c|c|c|}
\hline & & $n=64$ & \\
\hline Characteristic & Description & Frequency & Percentage \\
\hline \multirow[t]{3}{*}{ Gender } & Male & 47 & 73.4 \\
\hline & Female & 17 & 26.6 \\
\hline & Total & 64 & 100.0 \\
\hline \multirow{10}{*}{$\begin{array}{l}\text { Education } \\
\text { level }\end{array}$} & Elementary & & \\
\hline & & 3 & 4.7 \\
\hline & Junior secondary & 2 & 3.1 \\
\hline & High School & 27 & 42.2 \\
\hline & Certificate & 7 & 10.9 \\
\hline & Diploma & 11 & 17.2 \\
\hline & Degree & 14 & 21.9 \\
\hline & Masters & 0 & 0.0 \\
\hline & $\mathrm{PhD}$ & 0 & 0.0 \\
\hline & Total & 64 & 100.0 \\
\hline \multirow[t]{3}{*}{ Position held } & Owner & 18 & 28.1 \\
\hline & Manager & 46 & 71.9 \\
\hline & Total & 64 & 100.0 \\
\hline \multirow[t]{5}{*}{ Business Type } & Sole proprietorship & 35 & 54.7 \\
\hline & Partnership & 12 & 18.8 \\
\hline & Company & 10 & 15.8 \\
\hline & Government owned & 7 & 10.9 \\
\hline & Total & 64 & 100.0 \\
\hline
\end{tabular}

\section{Source: Field Data (2018)}

Results in Table 3 show that there is gender disparity in terms of the ratio of males (73.4\%) compared to females (26.6\%). This finding implies that the industry has a lot to do in terms of achieving gender parity or/and affirmative action in the area of placement. Contemporary organizations aim at bridging the gap between males and females in the working areas in the spirit of giving equal opportunities to both genders to ensure holistic societal development.

In terms of education levels of respondents; $4.7 \%$ had elementary education, $3.1 \%$ had junior secondary education, $42.2 \%$ had high school education, $10.9 \%$ had certificate level of education, 17.2\% were diploma holders, while $21.9 \%$ were bachelor's degree holders. No manager or ownermanager had either a Master's degree or a PhD. It is evident from these statistics that most managers or/and owner-managers had secondary level of education (45.3\%). This is not in tandem with the 
INTERNATIONAL JOURNAL OF ACADEMIC RESEARCH IN BUSINESS AND SOCIAL SCIENCES

Vol. 9, No. 1, Jan, 2019, E-ISSN: 2222-6990 (C) 2019 HRMARS

requirements for modern-day organizations given that contemporary organizations operate in a very competitive and dynamic business environment. Managers of contemporary organizations that are going concerns and profit making must possess high education qualifications that would enable them to think non-linearly and apply complex business models that would give them leverage over competition. Moreover, strategic management of organizations require a broad understanding of the various micro- and macro-environmental factors that affect sustainable performance of organizations and this requires an appreciable level of formal education.

With regard to the designated positions of the respondents, $28.1 \%$ were owner-managers while $71.9 \%$ were hired managers. With regard to the type of hotels ownership structure, $54.7 \%$ were sole proprietorships, $18.8 \%$ were partnerships, and $15.8 \%$ were companies while $10.9 \%$ were government owned.

\section{Data Analysis}

\section{Descriptive Statistics}

The respondents were asked whether their hotels had a business plan. Their responses were as summarised in Table 4 below.

Table 4: Availability of a Business Plan

\begin{tabular}{|c|c|c|c|c|c|}
\hline & & $\begin{array}{c}\text { Frequenc } \\
y\end{array}$ & Percent & $\begin{array}{l}\text { Valid } \\
\text { Percent }\end{array}$ & $\begin{array}{l}\text { Cumulative } \\
\text { Percent }\end{array}$ \\
\hline \multirow{3}{*}{ Valid } & Yes & 22 & 34.4 & 34.4 & \multirow{3}{*}{$\begin{array}{r}34.4 \\
100.0\end{array}$} \\
\hline & No & 42 & 65.6 & 65.6 & \\
\hline & Total & 64 & 100.0 & 100.0 & \\
\hline
\end{tabular}

Source: Field Data (2018)

From Table 4, 34.4\% of the respondents indicated that their hotels had business plans while $65.6 \%$ did not. These statistics show that majority of hotels in Eritrea have not fully embraced strategic management of their organizations given that business plans are key indicators of planned and deliberate management of contemporary organizations. This finding agrees with that of Lumpkin and Dess (1995) that found many small firms lack such strategic documents.

\section{Inferential Statistics}

To establish the relationship between strategic business practices and performance of hotels, both correlation and regression analysis were carried out. Table 5 gives the results for the correlation analysis. 
INTERNATIONAL JOURNAL OF ACADEMIC RESEARCH IN BUSINESS AND SOCIAL SCIENCES

Vol. 9, No. 1, Jan, 2019, E-ISSN: $2222-6990$ @ 2019 HRMARS

Table 5: Pearson's Correlation Results

\begin{tabular}{|c|c|c|c|c|c|c|c|}
\hline & & ST_1 & ST_2 & ST_3 & ST_4 & ST_5 & Tsales \\
\hline \multirow[t]{3}{*}{ ST_1 } & $\begin{array}{l}\text { Pearson } \\
\text { Correlation }\end{array}$ & 1 & & & & & \\
\hline & Sig. (2-tailed) & & & & & & \\
\hline & Pearson & $.598^{* *}$ & 1 & & & & \\
\hline ST_2 & $\begin{array}{l}\text { Correlation } \\
\text { Sig. (2-tailed) }\end{array}$ & .000 & & & & & \\
\hline \multirow{3}{*}{ ST_3 } & Pearson & $.543^{* *}$ & $.654^{* *}$ & 1 & & & \\
\hline & Correlation & & & & & & \\
\hline & Sig. (2-tailed) & .000 & .000 & & & & \\
\hline \multirow{2}{*}{ ST_4 } & $\begin{array}{l}\text { Pearson } \\
\text { Correlation }\end{array}$ & $.491^{* *}$ & $.764^{* *}$ & $.599^{* *}$ & 1 & & \\
\hline & Sig. (2-tailed) & .000 & .000 & .000 & & & \\
\hline \multirow[t]{2}{*}{ ST_5 } & $\begin{array}{l}\text { Pearson } \\
\text { Correlation }\end{array}$ & $.225^{*}$ & $.355^{* *}$ & $.490^{* *}$ & $.358^{* *}$ & 1 & \\
\hline & Sig. (2-tailed) & .0042 & .004 & .000 & .004 & & \\
\hline \multirow{2}{*}{ Tsales } & $\begin{array}{l}\text { Pearson } \\
\text { Correlation }\end{array}$ & $.422^{* *}$ & $.254^{*}$ & $.433^{* *}$ & $.339^{* *}$ & $.349^{* *}$ & 1 \\
\hline & Sig. (2-tailed) & .001 & .050 & .001 & .008 & .006 & \\
\hline
\end{tabular}

Note: *. Correlation is significant at the 0.05 level (2-tailed).

**. Correlation is significant at the 0.01 level (2-tailed).

Source: Survey Data (2018)

Results presented in Table 5 show that significant positive correlations exist between the independent variables (strategic business practices) and the dependent variable (sales growth).

\section{Regression Results}

Table 6: Goodness-of-Fit for Strategic Business Practices and Performance of Hotels

\begin{tabular}{lcccc}
\hline \multicolumn{5}{c}{ Model Summary $^{\mathrm{b}}$} \\
\hline Sample size & $\mathrm{R}$ & $\mathrm{R}$-square & $\begin{array}{c}\text { Adjusted R- } \\
\text { square }\end{array}$ & $\begin{array}{c}\text { Std. Error of the } \\
\text { Estimate }\end{array}$ \\
\hline 64 & $.583^{\mathrm{a}}$ & .340 & .278 & 36.80344 \\
\hline
\end{tabular}

Predictors: (Constant), Strategic Business Practices

Dependent Variable: Performance of Hotels

Source: Survey Data (2018) 
INTERNATIONAL JOURNAL OF ACADEMIC RESEARCH IN BUSINESS AND SOCIAL SCIENCES

Vol. 9, No. 1, Jan, 2019, E-ISSN: 2222-6990 (C) 2019 HRMARS

Results of Table 6 show the adjusted $\mathrm{R}^{2}=0.278$ meaning that strategic business practices (independent variables) account for $27.8 \%$ of the variations in the dependent variable (Sales growth).

Table 7: ANOVA for Strategic Business Practices and Performance of Hotels

\begin{tabular}{lccccc}
\hline \multicolumn{5}{c}{ ANOVA $^{\mathbf{b}}$} \\
\hline Model & $\begin{array}{c}\text { Sum of } \\
\text { Squares }\end{array}$ & df & Mean Square & F & Sig. \\
\hline Regression & 37046.342 & 5 & 7409.268 & 5.470 & $.000^{\mathrm{a}}$ \\
\hline Residual & 71788.129 & 53 & 1354.493 & & \\
\hline Total & 108834.471 & 58 & & & \\
\hline $\begin{array}{l}\text { Notes: a. Predictors: (Constant), Competitive pricing (ST_1), product specialization (ST_2), } \\
\text { corporate branding (ST_3), product differentiation (ST_4), employee training (ST_5) } \\
\text { b. Dependent Variable: Performance of hotels (Tsales) } \\
\text { Source: Survey Data (2018) }\end{array}$
\end{tabular}

Results of ANOVA in Table 7 show F-statistic of $F(5,53)=5.470$ and $p$-value $=0.000<0.05$. This means that the strategic business practices had a significant effect on the performance of hotels in Eritrea.

Table 8: Significance of the Regression of Strategic Business Practices and Performance of Hotels Coefficients $^{a}$

\begin{tabular}{|c|c|c|c|c|c|c|c|}
\hline \multirow[t]{2}{*}{ Model } & \multicolumn{2}{|c|}{$\begin{array}{l}\text { Unstandardized } \\
\text { Coefficients }\end{array}$} & \multirow{2}{*}{$\begin{array}{c}\text { Standardize } \\
\mathrm{d} \\
\text { Coefficients }\end{array}$} & \multirow[t]{2}{*}{$\mathrm{t}$} & \multirow[t]{2}{*}{ Sig. } & \multicolumn{2}{|c|}{$\begin{array}{l}\text { Collinearity } \\
\text { Statistics }\end{array}$} \\
\hline & $B$ & Std. Error & & & & Tolerance & VIF \\
\hline Constant & -31.590 & 16.163 & & -1.954 & .056 & & \\
\hline ST_1 & 12.438 & 5.199 & .336 & 2.393 & .020 & .633 & 1.581 \\
\hline ST_5 & -17.888 & 7.779 & -.511 & -2.299 & .025 & .252 & 1.965 \\
\hline ST_2 & 7.966 & 4.792 & .267 & 1.662 & .102 & .483 & 2.070 \\
\hline ST_3 & 12.536 & 6.749 & .365 & 1.858 & .069 & .322 & 1.102 \\
\hline ST_ 4 & 10.257 & 5.326 & .248 & 1.926 & .050 & .753 & 1.328 \\
\hline
\end{tabular}

Notes: a) Predictors: (Constant), ST_1, ST_2, ST_3, ST_4, ST_5

b) Dependent Variable: performance of hotels (Tsales)

Source: Survey Data (2018)

Table 8 shows that among the five explanatory variables, three variables were statistically significant; competitive pricing (ST_1) $(\beta=0.336, p=0.020<0.05)$, product differentiation (ST_4) $(\beta=0.248$, $p=0.05=0.05)$ and employee training (ST_5) $(\beta=-0.511, p=0.25<0.05)$. These findings concur with 
those of Qin, Adler \& Cai (2012), Njoroge (2013) and Musyoka (2016) that established hotels perform better where there is extensive staff training and more so where skills-set of the employees in different hotels are relevant to the mission of the firm. The findings are further supported by those of Ng'ang'a (2013) who identified extensive staff training, range of product offerings, unique product features, among others as being positively correlated with performance of hotels.

On the other hand, product specialization $(\beta=0.267, p=0.102>0.05)$ and corporate branding $(\beta=$ $0.365, p=0.069>0.05$ ) were not statistically significant. Owing to these findings, $\mathrm{H}_{\mathrm{a} 2}$ and $\mathrm{H}_{\mathrm{a} 3}$ are rejected. These results imply that hotels in Eritrea have not invested heavily on specialised product offerings and corporate branding; strategies that would be instrumental in appealing to their varied clientele. These findings are at variance with those of Qin, Adler \& Cai (2012) and Ng'ang'a (2013) who found that strong hotel branding and excellent customer service resulted into creation of new customer value which consequently led to improved revenue, strong market positioning and improved hotel sales and profitability.

\section{Conclusions and Recommendations}

From the descriptive statistics, $34.4 \%$ of the respondents indicated that their hotels had business plans while $65.6 \%$ did not. These statistics show that majority of hotels in Eritrea have not fully embraced strategic management of their organizations given that business plans are key indicators of planned and deliberate management of contemporary organizations. It is therefore recommended that the management teams of hotels should be more deliberate and intentional in embracing and using strategic management tools such as strategic plans, business plans and marketing plans, which are very crucial in a service industry like hotels. Moreover, the management teams of hotels ought to upgrade their education levels as the low academic qualification could in part account for the absence of such critical documents in a for-profit making and competitive industry like hotel.

The results of the regression analysis showed that competitive pricing, product differentiation and employees training were statistically significant and had a positive effect on performance of hotels in Eritrea. Owing to this finding, the study recommends continuous training of employees to match the rapidly changing needs of the global clientele, continuous innovation in order to continuously add value to the product offering as well as creating unique products; continuous market and marketing research in order to identify the changing tastes and preferences of customers as well as their consumer behaviour in order to competitively price their product offerings.

With regard to product specialization and corporate branding that were not statistically significant, it is recommended that the hotel management teams put rigor in identifying their areas of core competence and specialize in such areas in order to gain competitive advantage over competition. Smaller hotels can identify the market niches they can serve better and specialize in certain product/service provision. Moreover, it is recommended that hotel managers be more aggressive in corporate branding as it easily gives brand identity and visibility consequently improving market positioning of a company; a key performance feature of any enterprise that is a going concern. 
INTERNATIONAL JOURNAL OF ACADEMIC RESEARCH IN BUSINESS AND SOCIAL SCIENCES

Vol. 9, No. 1, Jan, 2019, E-ISSN: 2222-6990 @ 2019 HRMARS

\section{References}

Audretsch, D., \& Dohse, D. (2007). Location: A neglected determinant of firm growth. Review of World Economics, 143(1), 79-107.

Babbie, E.R. (2010). The practice of social research, (12 ${ }^{\text {th }}$ edition). California: Wadsworth-Cengage Learning.

Barney, J.B. (1991). Firm resources and sustainable competitive advantage. Journal of Management, $17(1), 99-120$.

Coad, A. (2009). The growth of firms: A survey of theories and empirical evidence, Edward Elgar, Cheltenham.

Coombs, J.G., Crook, T.R., \& Shook, C.L. (2005). The dimension of organisation performance and its implications for strategic management research and research methodology in strategy and management. San Diego. Elsevier, 259-286.

Cooper, D.R., \& Schindler, P.S. (2003). Business research methods: Irwin: McGraw-Hill.

Corgel, J. B. (2002). A hotel investment is only as good as its local market, Real Estate Issues, 27(2), 64-66.

Corgel, J.B. (2005). Hotel real estate markets. Journal of Portfolio Management, 32, 91-99.

Corgel, J.B. \& deRoos, J.A. (1997). Hotel investments in the portfolio: Are they part of the core? Real Estate Finance, 14(2), 29-37.

David, F.R. (2001). Strategic management concepts. Prentice Hall, Upper Saddle River, NJ.

Delmar, F., Davidsson, P., \& Gartner, W.B. (2003). Arriving at the high-growth firm. Journal of Business Venturing, 18(2), 189-216.

Gibson, B., and Cassar, G. (2005). Longitudinal analysis of relationships between planning and performance in small firms. Small Business Economics, 25(3), 207-222.

Gibuson, P., \& Kemp, R.G. (2005). Strategy and small business performance. Scientific Analysis of Entrepreneurship and SMEs.

Hayes, D.K., \& Ninemeier, J.D. (2007). Hotel operations management ( $2^{\text {nd }}$ ed.), Pearson Prentice Hall, Upper Saddle River, NJ.

Hitt, R.E., \& Freeman, H. (2005). Improving firm performance through strategy: The Academy of Management Executive MA.

Kaplan, R.S., \& Norton, D.P. (1992). The balanced scorecard measures that drive performance. Harvard Business Review, 70(1), 71-79.

Khan, M.M. \& Fasih, M. (2014). Impact of Service Quality on Customer Satisfaction and Customer Loyalty: Evidence from Banking Sector. Pakistan Journal of Commerce \& Social Sciences, 8, 331-354.

Kiiru, D.M. (2015). Strategic human resource management practices and performance of parastatals in Kenya. Doctoral thesis. Kenyatta University.

Kothari, C.R., \& Garg, G. (2014). Research methodology: Methods\& techniques (3 ${ }^{\text {rd }}$ ed.). New Age International Publishers, New Delhi, India.

Lee, C., \& Nowell, B. (2014). A framework for assessing the performance of non-profit organisations. American journal of evaluation, 36(3), 299-319. SAGE Publications. 
INTERNATIONAL JOURNAL OF ACADEMIC RESEARCH IN BUSINESS AND SOCIAL SCIENCES

Vol. 9, No. 1, Jan, 2019, E-ISSN: 2222-6990 @ 2019 HRMARS

Lumpkin, G.T., \& Dess, G.G. (1995). Simplicity as a strategy making process: The effect of stage of organizational development and environment on performance. Academy of Management Journal, 38(5), 1386-1407.

Mata, F.T., Fuerst, W.L., \& Barney, J.B. (1995). Information technology and sustainable competitive advantage: A resource based view analysis. MIS Quarterly Review, 19(4), 487-495.

Mintzberg, H. (1990). Strategy formulation: Schools of thought in Fredrickson, J.W. (Ed.) Perspectives on Strategic Management. Harper \& Row, New York, NY.

Musyoka, S.M. (2016). Factors that influence organizational performance in the hospitality industry: A case of Sankara Hotel, Nairobi, Kenya. MBA dissertation, United States International University Africa.

Neely, A., Mills, J., Platts, K., Richards, H., \& Gregory, M. (2000). Performance measurement system design: Developing and testing a process-based approach. International Journal of Operations, Production and Management, 20(10):

Ng'ang'a, A.W. (2013). Operational strategy and performance in the hotel industry: A study of hotels in Nairobi, Kenya. MBA dissertation, University of Nairobi, Kenya.

Njoroge, W.W. (2013). Employee factors and perceived service quality in the hotel industry in Nairobi. MBA dissertation, University of Nairobi, Kenya.

Nyheim, P., McFadden, F., \& Connolly, D. (2004). Technology strategies for the hospitality industry, Pearson Printice Hall, Upper Saddle River, NJ.

Okumus, F. (2002). Can hospitality researchers contribute to the strategic management literature? International Journal of Hospitality Management, 21(2), 105-110.

O'Neill, J.W. (2004). An automated valuation model for hotels. Cornell Hotel and Restaurant Administration Quarterly, 45(3), 260-268.

O’Neill, J.W., \& Mattila, A.S. (2010). Hotel brand strategy. Cornell Hotel and Restaurant Administration Quarterly, 51(1), 27-34.

O'Neill, J. W., \& Xiao, Q. (2006). The role of brand affiliation on hotel market value. Cornell Hotel and Restaurant Administration Quarterly, 47(3), 1-14.

Parker, S., Storey, D. \& Witteloostuijn, A. (2010). What happens to gazelles? The importance of dynamic management strategy. Small Business Economics, 35(2), 203-226.

Perry, S.C. (2001). The relationship between written business plans and failure of small business in the US. Journal of Small Business Management 39(3), 201-208.

Qin, Y., Adler, H., and Cai, L. A. (2012). Successful growth strategies of three Chinese domestic hotel companies, Journal of Management \& strategy, 3(1), 40-54.

Rhyne, L.C. (1986). The relationship of strategic planning to financial performance. Strategic Management Journal, 7(5), 423-436.

Santos, J.B., \& Brito, A.I.A. (2012). Towards subjective measurement model of firm performance. Brazilians Administration Review, Special Issue.

Saunders, M., Lewis, P., \& Thornhill, A. (2013). Research methods for business students, (6th ed.). Harlow: Prentice Hall Financial Times.

Saunders, M., Lewis, P., \& Thornhill, A. (2009). Research methods for business students, ( $5^{\text {th }}$ ed.). New Jersey: Prentice Hall: London.

Verreynne, M.L., \& Meyer, D. (2010). Making strategy at different stages of the industry 
INTERNATIONAL JOURNAL OF ACADEMIC RESEARCH IN BUSINESS AND SOCIAL SCIENCES Vol. 9, No. 1, Jan, 2019, E-ISSN: 2222-6990 @ 2019 HRMARS

life cycle - relationships with small firm performance. Small Business Economics, 4(3), 1-18. Waiganjo, E., Mukulu, E., \& Kahiri, J. (2012). Relationship between strategic human resource management and firm performance of Kenya's corporate organisations.

International Journal of Humanities and Social Science 2(1), 63- 68.

Zuriekat, M., Salameh, R., \& Alrawashdeh, S. (2011). Participation in performance measurement systems and level of satisfaction. International Journal of Business and Social Science, 2(8), 159-169. 